\title{
Effect of Dietary Supplementation of Curcuma Longa on the Biochemical Profile and Meat Characteristics of Broiler Rabbits under Summer Stress
}

\author{
Basavaraj, M., Nagabhushana, V*, Prakash, N., Appannavar, M.M., Prashanth Wagmare \\ and S.Mallikarjunappa \\ Department of Animal Nutrition, \\ Veterinary College, Karnataka Veterinary and Fishery Science University, \\ P.B.No.6, Bidar-585 401, INDIA. \\ * Corresponding author email : nkuliyadi@yahoo.com
}

\begin{abstract}
Eighteen four week's old weaned broiler rabbits of comparable body weights were allotted to three dietary treatment groups of six rabbits in each group namely T0 (basal control diet, T1 (basal diet added with turmeric rhizome powder, TRP, at the ratio of $150 \mathrm{mg}$ ) and T2 (basal diet added with TRP at the ratio of $300 \mathrm{mg} / 100 \mathrm{~g}$ diet). Different hematological and serum biochemical parameters such as packed cell volume, Hemoglobin, total erythrocyte count and total leukocyte count and serum total protein, albumin, cholesterol, alkaline phosphatase, alanine transaminase and aspartate transaminase due to the dietary inclusion of turmeric powder rhizome supplementation at $0,0.15$ and 0.30 percent did not show significant difference between the treatment groups. Carcass parameters and chemical composition of meat were closer to the standard values. The results of the study indicated no beneficial effect of dietary inclusion of turmeric (Curcuma longa) rhizome powder at $0,0.15$ and 0.30 per cent on blood biochemical and meat characteristics of broiler rabbits reared under summer stress.
\end{abstract}

Key words: Summer stress, turmeric, curcumin, antioxidant, rabbits

\section{I ntroduction}

Commercial rabbit production has been gaining much attention in recent years due to their high prolificacy, rapid growth rate, small body size and high meat yields. Rabbits can convert $20 \%$ of the protein they eat into edible meat which is higher than pigs (16-18\%), beef (8-12\%). In tropical climates where temperature hovers around $400{ }^{\circ} \mathrm{C}$ during summer hinders the commercial rabbit production. Bidar district of northern Karnataka, where average daily maximum temperature during study period was around $35-40{ }^{\circ} \mathrm{C}$.

Rabbits are highly susceptible to heat stress due to few functional sweat glands and evince difficulty in heat evaporation with increasing environmental temperature (Cheeke et al., 1987). They find difficulty in dissipating heat at high environmental temperatures. Heat load imposed upon rabbit can be alleviated through genetic, managerial or nutritional means. Supplementing heat stressed rabbits with cool water, (Habeeb et al., 1994) Vitamin C (Al-Shanty, 2003) mineral water (Marai et al., 1994) or enzyme mixture preparations (Tawfeek.1996) were found to help rabbit withstand heat stress. Herbal compounds like epigallocatechin (green tea catechin), curcumin, indole-3-carbinol, resveratol etc are currently undergoing clinical trials due to their chemopreventive and antioxidant properties (Greenwald, 2004). Turmeric (Curcuma longa) an extensively used spice, food preservative, and coloring material has biological actions and medicinal applications.

Curcumin has shown to have anti-inflammatory, antioxidant, anticarcinogenic, antimutagenic, anticoagu-lant, antidiabetic, antibacterial, antifungal, antiprotozoal, antiviral, antifibrotic, antivenom, antiulcer, hypotensive, and hypocholesterolemic activities. Curcumin reduces the activity of reactive oxygen species and elevates the antioxidant enzymes superoxide dismutase, catalase, and glutathione peroxidase levels in the blood (Joe and Lokesh, 1994). Keeping these points in view, the present study was carried out with the objective to study the effect of turmeric rhizome powder on growth, feed intake and feed efficiency in heat stressed broiler rabbits and on nutrient digestibility.

\section{Material and Methods}

Experimental animals and dietary treatments: Eighteen four weeks' old weaned Broiler rabbits of 
comparable body weights were selected for the study. They were randomly allotted to three dietary treatment groups of six rabbits in each group namely T0, T1 and T2. Experimental diets were prepared in the form of total mixed ration (TMR) using locally available ingredients such as spinach hay, 30 parts; maize, 28 parts; deoiled rice bran, 25 parts; soybean meal, 15 parts; mineral mixture, 1.5 parts; vitamin mixture, 0.2 parts; and salt, 05 parts, and the ration thus prepared was isonitrogenous and isocaloric. The TMR served as the basal control diet (T0) and the basal diet added with TRP at the ratio of $150 \mathrm{mg}$ and $300 \mathrm{mg} / 100 \mathrm{~g}$ diet were designated as $\mathrm{T} 1$ and $\mathrm{T} 2$ respectively. The rabbits were kept in individual cages $(15 \times 18 \times 11$ inches $)$ and were housed in a well ventilated laboratory animal house. Temperature and humidity of laboratory animal house was recorded daily at 8.00AM and 4.00PM for minimum and maximum values by using wet bulb and dry bulb thermometer.

Hematology and serum biochemistry: The feeding for a period of 8 weeks and a digestion trial at the end of feeding trial were conducted to assess the effect of TMR on voluntary feed intake, growth rate and nutrient digestibility. The blood was collected from each rabbit on the last day of experiment before slaughtering them for meat study. The blood was analyzed for hematological (Schalm 1965) and serum total protein, albumin (Valzitidis, H., 1977), Alkaline Phosphatase (ALP), Alanine Transaminase (ALT), Aspartate Transaminase (AST) (Reitman and Frankel, 1957) and Cholesterol (Gordan and Amer, 1977) estimation.

Carcass characteristics: Carcass parameters such as slaughter weight, dressing percent, total meat, and weight of offal's such as liver, heart, lungs with trachea were studied according to Gerrard (1977). Chemical composition of meat and bone were analyzed from the meat and bone collected. Protein and fat content in Longissimus dorsi muscle was analyzed. Calcium and phosphorous content of femur bone was analyzed according to A.O.A.C. (1990).

Data obtained were subjected to statistical analysis by using Sigmastat ${ }^{\circledR}$ and results were compared (Snedecor and Cochran 1985).

\section{Results and Discussion}

Hematological parameters: Different hematological and serum biochemical parameters influenced by the turmeric powder rhizome supplementation at 0 , 0.15 and 0.30 percent are presented in table: 1 . Blood hematology picture packed cell volume, Hemoglobin, total erythrocyte count and total leukocyte count did not show significant (P?0.05) difference between the treatment groups these results are in concurrence with Emadi et al. (2007) in chicken; Aengwanich and Chinarasri (2004) in chronic heat stressed broilers, who supplemented ascorbic acid at $200 \mathrm{mg} / \mathrm{kg}$ diet. It may be possibly due to not supplementing TRP at optimum concentration as Emadi et al. (2007) reported that at $0.50 \%$ level it elicited significant decrease in serum albumin and total red blood cells and increased hemoglobin concentration in chicken.

Serum biochemical parameters: Serum total protein, albumin, cholesterol, alkaline phosphatase, alanine transaminase and aspartate transaminase were not affected by dietary inclusion of turmeric rhizome powder at $0.15,0.30$ percent in $\mathrm{T} 1$ and $\mathrm{T} 2$ groups respectively. Emadi et al. (2007) reported that total protein and cholesterol levels as similar at TRP levels of $0.25,0.50$ and $0.75 \%$ in the diet of chicks but at $0.50 \%$ it decreased serum albumin levels. Curcumin decreased the cholesterol levels when atherogenic diet was fed to rabbits (Ramirez-Tortosa et al., 1999). Further curcumin significantly and dose dependently decreased the elevated levels of AST, ALT and ALP in serum of LPS-challenged rats (Kaur et al., 2006).

Carcass parameters and meat composition: The results of meat parameters such as live weight $(\mathrm{g})$, carcass weight (g), dressing percent, meat to bone ratio (Table: 2) are lower and chemical composition of meat

Table 1: Effect of turmeric rhizome powder on hematological parameters

\begin{tabular}{|c|c|c|c|}
\hline Parameters & TO & T1 & T2 \\
\hline $\operatorname{PCV}(\%)$ & $41.50 \pm 1.20$ & $41.33 \pm 2.11$ & $37.50 \pm 3.33$ \\
\hline $\mathrm{Hb}(\mathrm{g} / \mathrm{dl})$ & $15.62 \pm 0.30$ & $15.97 \pm 0.62$ & $14.70 \pm 0.51$ \\
\hline TLC $(1000 / \mathrm{mm} 3)$ & $7.10 \pm 0.71$ & $7.71 \pm 0.82$ & $6.92 \pm 0.77$ \\
\hline $\mathrm{TP}(\mathrm{g} / \mathrm{dl})$ & $06.83 \pm 0.20$ & $06.38 \pm 0.19$ & $06.76 \pm 0.21$ \\
\hline $\operatorname{ALB}(\mathrm{g} / \mathrm{dl})$ & $03.09 \pm 0.15$ & $03.00 \pm 0.14$ & $02.96 \pm 0.09$ \\
\hline AST (u/lit) & $46.64 \pm 2.82$ & $45.72 \pm 3.43$ & $46.84 \pm 1.47$ \\
\hline ALT (u/lit) & $77.33 \pm 2.37$ & $74.80 \pm 2.97$ & $75.68 \pm 1.55$ \\
\hline
\end{tabular}


Effect of Dietary Supplementation of Curcuma Longa on Broiler Rabbits under Summer Stress

Table 2: Effect of turmeric rhizome powder supplementation on carcass parameters and meat composition

\begin{tabular}{llll}
\hline Parameters & T0 & T1 & T2 \\
\hline Live weight (g) & $1098.33 \pm 21.66$ & $1068.33 \pm 44.97$ & $1080.00 \pm 31.72$ \\
Carcass weight (g) & $635.88 \pm 12.36$ & $616.60 \pm 32.94$ & $622.76 \pm 27.97$ \\
Offal's weight (g) & $41.03 \mathrm{a} \pm 01.11$ & $46.66 \mathrm{~b} \pm 01.77$ & $44.70 \mathrm{ab} \pm 01.46$ \\
Carcass-offal's weight & $594.68 \pm 12.11$ & $569.93 \pm 31.58$ & $578.05 \pm 26.57$ \\
Meat (g) & $369.28 \pm 07.22$ & $371.01 \pm 19.85$ & $358.68 \pm 16.06$ \\
Bone(g) & $213.70 \pm 06.05$ & $193.33 \pm 12.49$ & $209.75 \pm 09.65$ \\
Dressing (\%) & $54.18 \pm 00.83$ & $53.22 \pm 01.24$ & $53.42 \pm 01.26$ \\
Meat: bone & $01.74 \mathrm{a} \pm 00.02$ & $01.93 \mathrm{~b} \pm 00.02$ & $01.71 \mathrm{a} \pm 00.02$ \\
Dry matter & $25.93 \pm 0.19$ & $26.10 \pm 0.51$ & $28.87 \pm 1.54$ \\
Crude protein & $21.20 \pm 0.19$ & $20.78 \pm 0.48$ & $20.06 \pm 0.61$ \\
Fat & $1.65 \mathrm{a} \pm 0.38$ & $1.71 \mathrm{a} \pm 0.45$ & $04.29 \mathrm{~b} \pm 1.92$ \\
Ash (bone) & $47.47 \pm 2.16$ & $43.89 \pm 2.28$ & $49.18 \pm 1.91$ \\
Acidinsoluble ash (bone) & $00.44 \pm 0.11$ & $00.23 \pm 0.02$ & $00.44 \pm 0.06$ \\
Calcium (bone) & $19.12 \mathrm{a} \mathrm{b} \pm 1.04$ & $16.46 \mathrm{a} \pm 1.09$ & $19.68 \mathrm{~b} \pm 0.69$ \\
Phosphorous(bone) & $8.03 \mathrm{ab} \pm 0.47$ & $07.12 \mathrm{a} \pm 0.14$ & $08.33 \mathrm{~b} \pm 0.29$ \\
\hline
\end{tabular}

Note: Mean value bearing different superscripts in a row differ significantly $(P>0.05)$

was comparable with the values of Kalita et al. (2000). Lower values obtained in the present trial may be due to low energy intake, lower body weight gain due to summer stress. The results of carcass parameters showed no significant difference between the control and test groups. Similarly $0.25 \%$ level of turmeric did not affect carcass characteristics in chicks; however at $0.50 \%$ level TRP did improve the dressing percent of chicks, increased breast weight and mean thigh weight which was due to optimum antioxidant activity of turmeric at $0.5 \%$ level which stimulated protein synthesis by bird enzymatic system (Durrani et al., 2006).

The results of meat composition such as dry matter (25.93) and crude protein (21.20) are in concurrence with Kiran (2005), who reported the dry matter content of 26.05 and crude protein content of 21.52 in the meat of broiler rabbits. Where as total ash (47.47), calcium (19.12) and phosphorous (8.03) in the bone were higher than the values of total ash (43.59) calcium (16.27) and phosphorous (6.17) in the bone compared to previous study (Kiran (2005).

The results of meat composition did not differ significantly between the groups $\mathrm{T} 0, \mathrm{~T} 1$ and $\mathrm{T} 2$ and were in accordance with Dal Bosco et al. (2004) who did not find significant effect on composition of rabbit meat due to the addition of antioxidant. On the contrary, Sahin and Kucuk (2001) reported that Vitamin $\mathrm{C}$ and Vitamin E supplementation improved carcass qualities in heat stressed quails. The mean ether extract, calcium and phosphorous content of the meat and bone differed significantly however it is reported that chemical composition of rabbit meat varies extremely with lipid composition ranging from 3.6-8\% (Pla, et al., 2004).

\section{References}

1. A. O. A. C. (1990): Official Methods of Analysis, 15th edition. Association of Official Analytical Chemists, Washington, D.C.

2. Aengwanich, W., Chinarasri, O. (2004): The effect of ascorbic acid on the productive performance, red blood cell parameters and hetrophyl: Lymphocyte ratio in broilers under chronic heat stress. Thai Journal of veterinary medicine, 34(3): 103-110.

3. Al-Shanti, H. (2003): Using Vitamin C and sodium bicarbonate to alleviate the effects of heat stress on rabbit performance. Egyptian Poultry Sci. J., 23(1):129-139.

4. Cheeke, P.R., Patton.N.M., Lukefahr, S.D. And Mevitt, J.I. (1987): Rabbit production, Interstate Publishers, Danville III.

5. Dal Bosco, A., Castellini, C., Bianchi, L., MUGNAI, C.,(2004). Effect of dietary a-linolenic acid and Vitamin E on the fatty acid composition, storage stability and sensory traits of rabbit meat. Meat Sci. 66: 407-413.

6. Durrani, F.R., Mohammed Ismial, Asal Sultan, Shhail, S.M., Naila Chand And Durrani, Z. (2006): Effect of different levels of feed added turmeric (Curcuma longa) on the performance of broiler chicks. Journal of Agricultural and Biological Science, 1 (2):9-11.

7. Emadi, M., Kermanshahi, H. and Maroufyan, F. (2007). Effect of varying levels of Turmeric Rhizome powder on some blood parameters of broiler chickens fed corn - soya bean meal based diets. International Journal of Poultry Science, 69(50):345-348.

8. Gerrard Frank, (1977). A practical textbook for student and butcher. 5th edition Northwood Publishers Ltd, London.

9. Gordon, T. And M. Amer, (1977). Cardiovascular disease marker. Am. J. Med., 62: 707-714. 
10. Greenwald, P. (2004): Clinical trials in cancer prevention: current results and perspectives for the future. $J$. Nutr., 134:3507S-3512S.

11. Habeeb, A., Marai, F., El-Sayaid, G.H., Nessem, Z. (1994): Effects of internal and external cooling techniques on growth and physical functions of New Zealand White and Californian rabbits maintained under hot summer conditions of Egypt. Proc. Ist Int. conf. on Rabbit Prod. In hot climates, Cairo, Egypt 6-8 September 626-633.

12. Joe, B. And Lokesh, B.R. (1994): Role of capsaicin, curcumin and dietary n-fatty acids in lowering the generation of reactive oxygen species in rat peritoneal macrophages. Biochem. Biophys. Acta., 1224: 255-263.

13. Kalita P., Bhuyan R. And Konwar B.K., 2000. Carcass characteristics and meat composition of broiler rabbits on different dietary levels of protein and energy. Indian Vet. J., 77: 972-975.

14. Kaur, G., Tirkey, N., Bharrhn, S., Chanana, P., Richi, P. and Chopra, K., (2006). Inhibition of oxidative stress and cytokine activity by curcumin in amelioration of endotoxin induced experimental hepatotoxicity in rodents. Clinical and Experimental Immunology, 145: 313-321.

15. Kiran, L. (2005): Effect of jojoba (Simmondsia chinensis) meal on the performance of the broiler rabbits. M.V.Sc. thesis, KVAFSU Bidar.

16. Marai, I.F.M., El- Marry, K.A. and Nasr, A. S., (1994). Heat Stress And Its Amelioration With Nutritional, Buffering, Hormonal And Physical techniques for New Zealand white rabbits maintained under hot summer conditions of Egypt. Options Mediterra- neenness, 8 (supplement):475-487.

17. Pla, M., Pascuel, M. and Arind, B., (2004). Protein, fat and moisture content of retail cuts of rabbit meat evaluated with the NIRS Methodology, World Rabbit Science, 12: 149-158.

18. Ramirez-Tortosa, M.C., et.al. (1999): Oral administration of a turmeric extract inhibits LDL oxidation and has hypocholesterolemic effects in rabbit's experimental atherosclerosis. Atherosc lerosis, 147: 371-378.

19. Reitman, S. And Frankel, S., (1957). A calorimetric method for the determination of serum Glutamic, Oxaloacetic and Pyruvic transaminases. American Journal of Clinical Pathology, 28:56.

20. Sahin, K. and Kucuk, O. (2001): Effects of Vitamin C and Vitamin $\mathrm{E}$ on performance, digestion of nutrients and carcass characteristics of Japanese quails reared under chronic heat stress $\left(34^{\circ} \mathrm{c}\right)$. J. Anim. Physiol. Anim. Nutri., 85: 335-342.

21. Schalm, O.W., (1965). Veterinary hematology 2nd Edition Lea and Febiger Philadelphia U.S.A.

22. Snedecor, G.W. and Cochran, W.G. (1985): Statistical methods 8th Edition IOWA sate University press, Ames IOWA 50010

23. Tawfeek, M. (1996): Effect of feeding system and supplemental diet with kemzyme on growth, blood constituents, carcass traits and reproductive performance in rabbits under intensive production conditions, Egyptian Journal of Rabbit Science. 6(1):21-37.

24. Valzitidis, H., (1977). Estimation of total serum proteins by Biuret method. Clinical Chemistry.23:908. 